\title{
Mutagenesis
}

November 2014, Volume 29 Issue 6 Pages 457-465

http://dx.doi.org/10.1093/mutage/geu040

http://archimer.ifremer.fr/doc/00287/39799/

(c) The Author 2014. Published by Oxford University Press on behalf of

the UK Environmental Mutagen Society. All rights reserved. For

permissions, please e-mail: journals.permissions@oup.com.

\section{DNA adduct formation and induction of detoxification mechanisms in Dreissena polymorpha exposed to nitro-PAHs}

\author{
Châtel Amélie ${ }^{1,{ }^{*}}$, Faucet-Marquis Virginie ${ }^{2}$, Pfohl-Leszkowicz Annie ${ }^{2}$, Gourlay-Francé Catherine ${ }^{1}$, \\ Vincent Hubert Francoise ${ }^{1,3}$
}

\footnotetext{
${ }^{1}$ IRSTEA, Unite Rech Hydrosyst \& Bioproc, F-92761 Antony, France.

2 Univ Toulouse, INPT ENSAT, Lab Genie Chim, UMR CNRS 5503,Dept Bioproc \& Syst Microbiens, F31320 Auzeville Tolosane, France.

${ }^{3}$ IFREMER, Laboratoire de microbioologie-LNR, centre de Nantes, BP 21105, 44311 Nantes Cedex 03, France.
}

* Corresponding author : Amélie Châtel, email address : amelie.chatel@uco.fr

\begin{abstract}
:
Derived polycyclic aromatic hydrocarbons (PAHs) such as nitro-PAHs are present in the environment and are known to be much more toxic than PAHs compounds. However, very few studies have analysed their effects on the aquatic environment and none have investigated the freshwater environment. In the present study, we determined whether 1-nitropyrene (1-NP), a model of nitro-PAHs, can induce DNA adducts in gills and digestive glands of the freshwater mussel Dreissena polymorpha. Two concentrations of 1-NP (50 and $500 \mathrm{mu} \mathrm{M}$ ) were tested. In addition, in order to understand the metabolic pathways involved in 1-NP genotoxicity, mRNA expression of genes implicated in biotransformation mechanisms was assessed by quantitative reverse transcription-PCR. Results showed the presence of DNA adducts in both gills and digestive glands, with highest levels obtained after 5 days of exposure to $500 \mathrm{mu}$ M. Metallothionein mRNA levels were enhanced in digestive glands exposed to $50 \mathrm{mu}$ M. Surprisingly, at the higher concentration (500 mu M), aryl hydrocarbon receptor and HSP70 genes were only up-regulated in digestive glands while PgP mRNA levels were increased in both tissues. Results suggested a cytotoxic and genotoxic effect of 1-NP. Mussels seemed to be able to partially detoxify this compound, in view of the low amount of DNA adducts observed after 5 days exposure to $50 \mathrm{mu}$ M. For the first time, 1-NP biotransformation and detoxification systems have been characterised in D. polymorpha.
\end{abstract}




\section{Introduction}

Among contaminants found in urban environment, organic pollutants such as polycyclic aromatic hydrocarbons (PAHs) and their derivatives like nitro-PAHs, are produced in high quantities by combustion of organic compounds (1). Nitrated polycyclic aromatic hydrocarbons (NPAHs) as nitropyrene and dinitropyrene are known to be carcinogens and mutagens $(2,3)$. Due to their strong mutagenic activity at very low concentrations, their effects on humans have been investigated and DNA adducts have been controlled (4). The main source of NPAHs are resulting from incomplete combustion of organic compounds such as diesel and gasoline (5) but also from the reaction between polycyclic aromatic hydrocarbons (PAHs) and nitrogen oxides in ambient air (6). 1-Nitropyrene (1-NP) is the most abundant nitro-PAHs in diesel exhaust particles and thirty percent of the direct mutagenicity of diesel is due to 1-NP (7). In the Paris Suburb, NPAHs have been reported in the atmosphere $(8,9,10,11,12,13)$. Even though nitro-PAHs are mainly present in the atmosphere of urban areas, they have also been found in aquatic environments (14) as well. However, very few studies have reported their effects in freshwater and seawater environments $(14,15)$.

Genotoxicity end points have been demonstrated to be reliable markers of PAHs exposure in aquatic environment. Indeed, biomarkers of DNA alteration (DNA strand breaks, micronuclei or DNA adducts) have been reported to be trustworthy indicators of genotoxic impact of pollutants in zebra mussels Dreissena polymorpha, a freshwater mussel largely used for biomonitoring in lakes and in rivers $(16,17,18,19)$. DNA adducts are chemicals resulting from xenobiotic metabolization that covalently bind to DNA (20). Several studies have demonstrated the interest of using DNA adducts $(21,22,23)$ to evaluate biological effects of chemical contamination in water. DNA adduct formation was observed in both marine mussels $(24,25,22)$ and freshwater mussels $(21,22,26)$, exposed to model PAHs. However, nitro-PAH effects on aquatic organisms have not been studied so far even though they represent the main mutagenic contaminants from urban areas (4).

1-NP is known to be converted into reactive nitrenium ions in vertebrates and invertebrates cells. It has a strong affinity/reactivity with the C8 atom of guanine nucleotides of DNA and lead to bulky hydrophobic lesions in the genome $(27,28)$ as well as the formation of N(deoxyguanosine-8-yl)-1-aminopyrene (APG) adduct (29). This compound is a direct 
mutagenic compound at low concentrations (pg/1). In the Brown trout and the turbot, 1-NP causes DNA adducts in vitro and in vivo as well as the activation of detoxification mechanisms (30). Further it was demonstrated that 1-NP caused mutations and apoptosis in liver cells through induction of Akt, ERK1/2, p38 and JNK phosphorylation (2). 1-NP has also been shown to increase intracellular levels of reactive oxygen (ROS) in human cells (31). In mussels, very few studies have shown the genotoxic effect of 1 NP (30). In only two studies, invertebrates (particularly, marine mussels and oysters) have been exposed to nitropyrene. Among them, only one laboratory study analyzed the toxicity of this compound (30) whereas the other was a field study where bioaccumulation of nitropyrene in mussels and oyster was evaluated (32). In the marine mussel, it has been demonstrated that the cytochrome P450 inhibition prevented the formation of DNA stand breaks by 1-NP, indicating that 1-NP biotransformation via P450 led to DNA damage (30).

Proteins known to be implicated in PAHs biotransformation in Mammals, have also been characterized in mussels: Aryl hydrocarbon receptor (AHR), cytochrome P450 (CYP1a) (phase I), gluthatione S-transferase (GST) (phase II), superoxide dismutase (SOD) and catalase (CAT) $(33,34)$. It has been accepted in Mammals that PAHs enter cells through the Aryl hydrocarbon receptor (AHR) thanks to the lipophilic properties of this nuclear receptor. Once into cells, AHR receptor/PAH complex act as a transcription factor for many genes. Treatment of hepatocyte human cell line with 1-NP resulted in an increase of both, CYP1A gene expression and CYP1A protein activation via the Akt pathway but induced AHR activity in a less manner than benzopyrene (35), indicating that 1-NP signalling pathway did not implicate AHR recruitment.

Genes encoding phase I and II proteins were recently sequenced in the mussel D. polymorpha (34). The superoxide dismutase (SOD) represents the first defensive system against reactive oxygen species (ROS) production since it catalyses the dismutation of $\mathrm{O}^{2-}$ to $\mathrm{H}_{2} \mathrm{O}_{2}$. The catalase (CAT) catalyses the reduction of $\mathrm{H}_{2} \mathrm{O}_{2}$ into $\mathrm{H}_{2} \mathrm{O}$, whereas the glutathione Stransferase (GST) represents among others, one of the most important detoxification phase II enzymes (33), in terms of quantity. It catalyses conjugaison reaction of glutathione with xenobiotics but also plays a role in preventing oxidative damage by conjugating breakdown products of lipid peroxides to GSH (36). The HSP70 and the transmembrane protein transporter P-gp1 act as efluxing xenobiotics out of cells $(37,38,39)$. 
In Invertebrates, metallothionein (MT) is also widely thought to play an important role in metal detoxification and in protecting cells against oxidative stress, notably nitrosation (40, $41,42,43,44)$.

The objective of this study was to evaluate the relevance of DNA adducts as biomarker of urban pollution in freshwater mussels.

For the first time in the present study, the effects of the major nitro-PAH, 1-NP, on the freshwater mussel Dreissena polymorpha were investigated. Mussels were exposed in laboratory to 1-NP and detection of DNA adducts was assessed using ${ }^{32} \mathrm{P}$ post labelling assay. Moreover, in order to characterize which parts of the metabolic pathways were involved in 1NP-mediated genotoxicity, expression of genes implicated in phase I and II detoxification mechanisms were analysed by quantitative RT-PCR.

\section{Material and methods}

\section{Mussel sampling and maintenance conditions}

Adult zebra mussels Dreissena polymorpha, 18-22mm long, were collected in March 2011 in a reference site Vertuzey (France) $\left(48^{\circ} 45^{\prime} 33^{\prime \prime} \mathrm{N}, 5^{\circ} 36^{\prime} 05^{\prime \prime} \mathrm{W}\right)$. Animals were transferred to laboratory, cleaned of all fouling organisms and kept in water $\left(16^{\circ} \mathrm{C}\right)$ for 10 days acclimation before the experiments.

\section{In vivo exposure of zebra mussels to nitropyrene}

Mussels were exposed to 1-Nitropyrene 50 and $500 \mu \mathrm{M}$ (N22959 Sigma) diluted in 0.001\% DMSO for $48 \mathrm{~h}$ or 5 days in glass tanks containing $12 \mathrm{~L}$ of Aquarel water (Nestlé), under artificial light and without feeding. Control mussels were incubated in water containing $0.01 \%$ DMSO as a solvent carrier. Media were completely renewed every two days. Digestive glands and gills (20 mussels per condition) were dissected at $48 \mathrm{~h}$ and 5 days after the beginning of exposure. The animals that had not attached to the tank were removed regularly. Tissues were then stored at $-80^{\circ} \mathrm{C}$ for further analysis.

\section{${ }^{32}$ P postlabelling Analysis of $\mathrm{DNA}$ adducts}

DNA isolation

DNA isolation has been done as described (45). In brief, digestive glands or gills were homogenized in a solution containing $\mathrm{NaCl}(0.1 \mathrm{M})$, EDTA $(20 \mathrm{mM})$ and Tris- $\mathrm{HCl}, \mathrm{pH} 8(50$ 
$\mathrm{mM})(\mathrm{SET})$. Proteins were precipitated by addition of SDS and potassium acetate $(6 \mathrm{M}, \mathrm{pH}$ 5). The supernatant, which contained nucleic acids, was collected and nucleic acids were precipitated overnight at $-20{ }^{\circ} \mathrm{C}$ by adding 2 volumes of cold ethanol. RNAs were eliminated following treatment by RNase A and RNase T1. Samples were then treated with proteinase K solution $(20 \mathrm{mg} / \mathrm{mL} \mathrm{SET})$ for $1 \mathrm{~h}$ at $37^{\circ} \mathrm{C}$. After digestion, DNA was extracted by rotiphenol (phenol saturated by Tris). The aqueous phase was collected after two extractions. After a final extraction with one volume of chloroform/isoamyl alcohol (24:1), the aqueous phase was collected. DNA was precipitated by addition of two volumes of cold ethanol overnight at $-20^{\circ} \mathrm{C}$. DNA purity was checked by recording UV spectra between 220 and $320 \mathrm{~nm}$.

\section{${ }^{32} P$ postlabelling}

DNA adducts were detected using the validated nuclease $P_{1}$ enrichment method (46) and the separation was performed after contact transfer (45). In brief, DNA (4 $\mu \mathrm{g})$ was digested at 37 ${ }^{\circ} \mathrm{C}$ for $4 \mathrm{~h}$ with $10 \mu \mathrm{L}$ of the mix containing micrococcal nuclease and spleen phosphodiesterase. The digested DNA was then treated with nuclease P1 at $37^{\circ} \mathrm{C}$ for $45 \mathrm{~min}$. DNA adducts were labeled as follows. To the NP1 digest, $5 \mu \mathrm{L}$ of the reaction mixture containing $2 \mu \mathrm{L}$ of bicine buffer [Bicine $(800 \mu \mathrm{M})$, dithiothreitol $(400 \mathrm{mM}), \mathrm{MgCl} 2$ (400 $\mathrm{mM})$, and spermidine $(400 \mathrm{mM})$ adjusted to $\mathrm{pH} 9.8$ with $\mathrm{NaOH}], 9.6 \mathrm{U}$ of polynucleotide kinase T4, and $100 \mu \mathrm{Ci}$ of [32P]ATP (specific activity $6000 \mathrm{Ci} / \mathrm{mmol}$ ) was added and incubated at $37{ }^{\circ} \mathrm{C}$ for $45 \mathrm{~min}$. Normal nucleotides, pyrophosphate, and excess ATP were removed by chromatography on PEI/cellulose TLC plates in $3 \mathrm{M} \mathrm{NaH}_{2} \mathrm{PO}_{4}$ buffer, pH 5.7, overnight (D1). The origin areas containing labelled adducted nucleotides were cut out and transferred to another PEI/cellulose TLC plate, which was run in $4.8 \mathrm{M}$ lithium formate and 7.7 M urea ( $\mathrm{pH} 3.5$ ) for $3 \mathrm{~h}$ (D2). A further migration was performed after turning the plate $90^{\circ}$ anticlockwise in 0.6 M NaH2PO4 and 5.95 M urea (pH 6.4) for $2 \mathrm{~h}$ (D3). Finally, the chromatogram was washed in the same direction with $1.7 \mathrm{M} \mathrm{NaH}{ }_{2} \mathrm{PO} 4, \mathrm{pH} 6$, for $2 \mathrm{~h}$ (D4). The $\mathrm{N} 2 \mathrm{dG}$ B[a]P adduct obtained during the EU project (46) was run in the same conditions and served as standard.

Radioactive spots were detected by autoradiography on Kodak super X-Ray film. Autoradiography was carried out in the presence of an intensifying screen at $-80{ }^{\circ} \mathrm{C}$ for $48 \mathrm{~h}$ (47). The radioactivity was measured by a phosphor imager as described below. 


\section{Quantitation of total DNA Adducts}

For the quantification of total DNA adducts, the TLC plates were then placed in a storage phosphor cassette containing a storage phosphor screen (Amersham) and exposed overnight. Results were digitized using a storage phosphor imaging system (Typhoon ${ }^{\mathrm{TM}}$ 9210, Amersham) and quantitated using ImageQuant ${ }^{\mathrm{TM}} 5.0$ software. After background subtraction, the levels of DNA adducts were expressed as relative adduct labelling (RAL) in total nucleotides. To calculate the levels of screen response (screen pixel) in dpm (disintegration per minute), samples of ${ }^{32} \mathrm{P}$-ATP at different concentrations from 10 to $500 \mathrm{dpm}$ were appropriately diluted and spotted on TLC plate. This TLC plate was then analysed on the Typhoon with the samples to obtain a radioactivity scale. The sensitivity allows detection of nitro-PAH adduct as low as 0.1 adduct/ $10^{10}$ nucleotides.

\section{RNA extraction, RT-PCR and $q R T-P C R$ analysis}

Total RNA from control and exposed mussels was extracted using TRIzol Reagent as described by (48). RNA concentration and purity was measured by spectrophotometric absorption at 260 and $280 \mathrm{~nm}$. First strand cDNA synthesis was carried out on $1 \mu \mathrm{g}$ of total RNA extract with oligo-dT primers according to Improm II Reverse Transcriptase kit (Promega). Preparations of digestive glands and gills cDNA were used to quantify specific transcripts in LightCycler 480 Real Time PCR System (Biorad) using SYBR Green Power Master Mix (Invitrogen) with the primers pairs listed in table 1. Relative mRNA abundances of different genes were calculated from the second derivative maximum of their respective amplification curves (Cp). Cp values for target genes (TG) were compared to the corresponding values for a reference gene (ribosomal S3 gene) to obtain $\Delta \mathrm{Cp}$ values $(\Delta \mathrm{Cp}=$ Cpref - CpTG). PCR efficiency values for reference and tested genes were calculated as described (49).

\section{Statistical analysis}

Adduct and RT-qPCR results are given as mean values \pm S.D. of 3 values ( 3 mussels per condition pooled and 3 repetitions for each test). The measured values were compared among different groups using the non parametric test Mann Whitney. Statistical significance was accepted at a $\mathrm{P}<0.05(*), \mathrm{P}<0.01(* *)$ and $\mathrm{P}<0.001(* * *)$. 


\section{Results}

\subsection{DNA adduct formation}

An example of DNA adduct patterns was presented in Fig 1. In gills of mussels treated with 1-nitropyrene, five different adducts (numbered \# 1- 5) were formed. In digestive glands mainly the two adducts \# $1 \& 2$ were observed. One other adduct (\# 6) was specifically formed in digestive glands after five days of exposure.

In gills, mainly the three DNA adducts (\# 1, 2, 3) were formed after $48 \mathrm{~h}$ exposure to 50 and $500 \mu \mathrm{M}$ of 1-Nitropyrene (1-NP). The total amounts of DNA-adducts were more intense when mussels were exposed to $500 \mu \mathrm{M}$ NP-1 during $48 \mathrm{~h}$ compared to $50 \mu \mathrm{M}$ (0.59 versus 1.08 adducts $/ 10^{9}$ nucleotides for 50 and $500 \mu \mathrm{M}$, respectively). After 5 days of exposure, a dramatic decrease of DNA adduct formation occured in gills exposed to the lowest dose $(50 \mu \mathrm{M})$. Both, the number of individual adducts and the total amount of DNA adducts decreased. Only the adduct \# 3 persisted and reached 0.2 adducts $/ 10^{9}$ nucleotides. In contrast, in gills exposed for 5 days to $500 \mu \mathrm{M}$, a larger amount of individual adducts were formed getting to a total of 6.44 adducts $/ 10^{9}$ nucleotides. The total amount of the three adducts $(\# 1,2$, 3) were about four times higher after 5 days of exposure to $500 \mu \mathrm{M}$ compared to $48 \mathrm{~h}$ exposure to $500 \mu \mathrm{M}$ (1.08 versus 4.14 adducts $10^{9}$ nucleotides) (Fig.2A).

In digestive glands, no significant DNA adducts was detected after $48 \mathrm{~h}$ of exposure whatever the concentration of 1-NP used. After 5 days of exposure, three DNA-adducts $(\# 1,2,6)$ were observed. The amount was much higher after the exposure to $500 \mu \mathrm{M}$ compared to $50 \mu \mathrm{M}$ (1.82 versus 7.18 adducts $/ 10^{9}$ nucleotides).

The highest amount of DNA adducts were noticed in both, gills and digestive glands exposed to the highest concentration $(500 \mu \mathrm{M})$ during 5 days. Notwithstanding, the pattern was not the same. Amount of adduct \# 1 in digestive glands was three times higher than in gills. Adducts (\# 3,4,5) were only formed in gills, while adduct \#6 was only formed in digestive glands (Fig. 2B).

\subsection{Gene expression}

Expression of genes implicated in detoxification mechanisms was investigated using quantitative RT-PCR. S3 ribosomal gene was chosen as the reference gene for gene expression normalization as previously demonstrated $(26,50)$. 
Generally, mussel exposure to low concentration of 1-NP only present an increase of PgP mRNA levels in gills and MT mRNA levels in digestive glands. Following exposure to the highest dose, mussels only depicted an increase of AHR, HSP70 and PgP genes expression in digestive glands whereas in gills, all of the genes studied were enhanced.

In gills exposed to 50 and $500 \mu \mathrm{M}$ (Fig. 3A) nitropyrene, AHR mRNA levels were significantly decreased compared to control. The same result was also observed in digestive glands exposed to $50 \mu \mathrm{M}$. In contrast, a $500 \mu \mathrm{M} 1-\mathrm{NP}$ concentration upregulated AHR mRNA as compared to control mussels (Fig. 4A).

Concerning the catalase gene expression, difference with the control levels was not significant in gills contrarily to the digestive glands where its expression was significantly downregulated both after exposure to 50 and $500 \mu \mathrm{M}$, with lowest levels registered after 5 days of treatment (Fig. 3B; Fig. 4B).

Whatever the concentration and the duration of exposure to 1-NP, SOD mRNA expression was also significantly decreased in gills and digestive glands (Fig. 3C; Fig. 4C).

GST mRNA level was significantly diminished in gills exposed to 1-NP for $48 \mathrm{~h}$ while in digestive glands, the decrease was significant for both concentrations at $48 \mathrm{~h}$ and 5 days (Fig. 3D; Fig. 4D).

MT mRNA expression was significantly reduced in gills exposed to 50 and $500 \mu \mathrm{M} 1$-NP for $48 \mathrm{~h}$ and 5 days as well as in digestive glands after exposition to $500 \mu \mathrm{M}$. However, mRNA expression was slightly increased in mussels exposed to $50 \mu \mathrm{M}$ for $48 \mathrm{~h}$ (Fig. 3E; Fig. 4E).

In gills, HSP70 mRNA levels were significantly lowered after 5 days of exposure to $50 \mu \mathrm{M} 1$ NP. In the digestive glands, first, HSP70 mRNA levels were significantly dropped after 5 days of exposure to 50 and $500 \mu \mathrm{M} 1 \mathrm{NP}$, then, an increase was observed after $48 \mathrm{~h}$ exposure to $500 \mu \mathrm{M}$ 1-NP (Fig. 3F; Fig. 4F).

Finally, in the digestive glands, PgP mRNA levels were highly increased after $48 \mathrm{~h}$ and 5 days exposure to $500 \mu \mathrm{M}$ 1-NP when in gills, 5 days was necessary to see that change (Fig. 3G; Fig. 4G). 


\section{Discussion}

The present study highlights for the first time the effects of 1-Nitropyrene on the formation of bulky DNA adducts in a freshwater organism, the zebra mussel D. polymorpha. In addition, so as to get a better understanding of the signalling pathway leading to this genotoxicity, expression of genes implicated in detoxification mechanisms was assessed by quantitative RT-PCR. All biomarker responses are summarized in table 2.

\section{DNA adduct formation}

In the present study, we demonstrated that 1-NP induces DNA adducts in zebra mussels. The amount of total DNA adducts detected in gills and digestive glands, ranging from below limit of quantification (LOQ) to 7.18 per $10^{9}$ nucleotides, are comparable to those obtained with $\mathrm{BaP}$ for zebra mussel $(21,26)$ and for marine mussels $(51,24,52)$.

These results demonstrate that freshwater mussels are able to rapidly biotransform 1-NP into compounds that have a strong affinity to DNA, hence forming DNA adducts. Biotransformation can lead in a major way to $\mathrm{N}$-(deoxyguanosine-8-yl)-1-aminopyrene adduct (29) and to other minors adducts (53), however DNA adducts spots cannot be identified due to lack of adducts standards.

This study is the first that analyze the impact of 1-NP on DNA adduct formation in invertebrates. In fishes, such as the Brown trout and the turbot, 1-NP has been demonstrated to induce DNA adducts both in vitro and in vivo as well as activation of detoxification mechanisms (30).

Gills, as the first tissue in contact with water, are constantly exposed to dissolved contaminants and are capable of metabolizing mutagens and carcinogens such as PAHs into reactive products in the digestive glands $(54,30)$. Globally more adducts are formed in digestive glands especially after 5 days of exposure. Moreover the pattern is different. This indicates that the detoxifying pathway is less effective in digestive gland compared to gills, and that the biotransformation pathways are different. This could be due also to a bioaccumulation of the pollutant in digestive glands. Similar results were also observed in the marine mussel M. galloprovincialis exposed to B[a]P (55). It has been suggested that tissuespecific enzymes like the cytochrome P450 could induce the formation of different metabolites during pollutant biotransformation processes and hence contribute to form different kind of DNA adducts in gills and in digestive glands (24), explaining the difference 
in DNA adduct levels observed between these two tissues in terms of total quantity and adduct profiles.

As a whole, in both tissues, it appears that DNA repair mechanisms were not sufficient enough to remove DNA adducts. Among the DNA repair pathways existing in Mammals, the nucleotide excision repair (NER) is mainly involved in bulky DNA adducts removing (56), and especially the PCNA protein (Proliferating Cell Nuclear Antigen), activated in mussels exposed to PAHs, is known to bind to DNA for DNA repair $(56,67,58)$.

\section{Expression of metabolization and detoxification genes}

Since studies concerning mechanisms implicated in 1-NP detoxification in invertebrates are still unknown, gene expression analysis in the freshwater mussel exposed to 1-NP has been performed using quantitative RT-PCR, according to the primer sequences published by (50, 34). As referred to this latter work, S3 ribosomal gene was chosen as the reference gene for gene expression normalization and t0 was used as control of the experiment.

Results showed that in gills AHR, CAT, SOD, GST, HSP70 and MT mRNA were downregulated after 1-NP mussel exposure. On the contrary, in digestive glands, at the highest concentrations, AHR and HSP70 genes were up-regulated whereas MT expression was enhanced at both concentrations. Only PgP mRNA expression was increased at higher concentration of 1-NP in both organs.

1-NP is reported to increase the intracellular level of reactive oxygen species (ROS) and the expression of pro-inflammatory cytokines in human lung epithelial cells $(59,31,60)$. It appears in our conditions that at low concentration, proteins implicated in detoxification mechanisms already present in cells (catalase, SOD, GST...) might not be sufficient to detoxify 1-NP, assessed by the presence of DNA adducts and by a down-regulation of all gene expressions except MT in digestive glands. Even though MT is known to play an important role in detoxification mechanisms and particularly through oxygen free radical scavenging actions (41), its expression is not correlated with a decrease in DNA adducts nor with an induction of the other genes implicated in oxidative stress.

On the contrary, highest doses of 1-NP increase the metabolization/detoxification gene expression which does not allow DNA adducts removal. Those high levels of DNA adducts in both organs could be due to mutations of DNA repair enzymes as demonstrated in E. Coli strains (61). 
It was observed an induction of apoptosis in an hepatocyte cell line exposed in vitro to 10 and $30 \mu \mathrm{M}$ 1-NP through activation of AMP-dependent protein kinase (AMPK) and caspase 3 (62). Other authors demonstrated in the same cell line, that 1-NP induced p53 expression, apoptosis and S-phase arrest (63).

Nevertheless, in this study, it seems that 1-NP effects on digestive gland cells occurred through the recruitment of AH-R (Aryl Hydrocarbon receptor), as previously demonstrated for benzo[a]pyrene in the same species (26). The inactive AH-R, present in the cytoplasm, is bound to two molecules of HSP90 stress protein. Ligand binding to AH-R results in the dissociation of HSP90 and the association with ARNt (AH receptor nuclear translocator) and the complex hence formed, acts as a transcription factor for many genes such as CYP450 family and other enzymes $(64,65)$. In the mammalian system, the major pathway of 1 -NP has been suggested to occur through the recruitment of the cytochrome P450 $(66,31)$.

HSP70 gene expression was also induced with high concentration of 1-NP in digestive glands. Its expression was enhanced in marine and freshwater mussels exposed to PAHs such as benzo(a)pyrene $(67,26)$, with a correlation to the formation of DNA adducts and oxidative damage $(68,26)$.

$\mathrm{PgP}$ is a part of the multixenobiotic resistance (MXR) mechanism, an established marker of xenobiotic exposure and especially PAHs exposure (69). In this study, PgP gene expression was improved in both gills and digestive glands exposed to the highest concentration of 1-NP. $\mathrm{PgP}$ is involved in the excretion of xenobiotics and operates non-specifically, exporting nonmetabolized parent xenobiotics, but also their metabolites and waste products derived from potential cell damage (70). In general, PAHs have been shown to induce PgP expression (71).

\section{Conclusion - Perspectives}

For the first time, the genotoxic impact of 1-Nitropyrene on the freshwater mussel $D$. polymorpha was analysed. We showed i) that this specie is able to metabolize this compound, assessed by the formation of DNA adducts and ii) tissue specific differences in biotransformation mechanisms. Henceforth, future investigations are needed to particularly identify apoptosis or reparation mechanism induction in the same conditions so as to clearly understand detoxification mechanisms activated in response to 1-nitropyrene exposure in $D$. polymorpha. 


\section{References}

8. Albinet, A., Leoz-Garziandia, E., Budzinski, H., Villenave, E. (2007) Polycyclic aromatic hydrocarbons (PAHs), nitrated PAHs and oxygenated PAHs in ambient air of the Marseilles area (South of France): concentrations and sources. Sci Total Environ., 384(1-3), 280-92.

23. Al-Subiai, S.N., Arlt, V.M., Frickers, P.E., Readman, J.W., Stolpe, B., Lead, J.R., Moody, A.J., Jha, A.N. (2012) Merging nano-genotoxicology with eco-genotoxicology: An integrated approach to determine interactive genotoxic and sub-lethal toxic effects of C(60) fullerenes and fluoranthene in marine mussels, Mytilus sp. Mutat. Res., 745(1-2), 92-103.

52. Akcha, F., Izuel, C., Venier, P., Budzinski, H., Burgeot, T., Narbonne, J.F. (2000) Enzymatic biomarker measurement and study of DNA adduct formation in benzo[a]pyrene contaminated mussels, Mytilus galloprovincialis. Aquatic Toxicology, 49, 269-287.

47. Amat-Bronnert, A., Castegnaro, M., Pfohl-Leszkowicz, A. (2007) Genotoxic activity and induction of biotransformation enzymes in two human cell lines after treatment by Erika fuel extract. Env. Toxicol. Pharmacol., 23(1), 89-95.

18. Bacchetta, R. and Mantecca, P. (2009) DDT polluted meltwater affects reproduction in the mussel Dreissena polymorpha. Chemosphere, 76(10), 1380-1385.

69. Bard, S.M. (2000) Multixenobiotic resistance as a cellular defense mechanism in aquatic organisms. Aquat. Toxicol., 1, 357-389.

16. Binelli, A., Bacchetta, R., Vailati, G., Galassi, S., Provini, A. (2001) DDT contamination in Lake Maggiore (N. Italy) and effects on zebra mussel spawning. Chemosphere, 45(4-5), 409-415.

19. Bourgeault, A., Gourlay-France, C., Vincent-Hubert, F., Palais, F., Geffard, A., BiagiantiRisbourg, S., Pain-Devin, S., Tusseau-Vuillemin, M.H. (2010) Lessons from a transplantation of zebra mussels into a small urban river: An integrated ecotoxicological assessment. Environ. Toxicol., 25, 468-78.

51. Canova, S., Degan, P., Peters, L.D., Livingstone, D.R., Voltan, R., Venier, P. (1998) Tissue dose, DNA adducts, oxidative DNA damage and CYP1A-immunopositive proteins in mussels

exposed to waterborne benzo[a]pyrene. Mutat. Res., 399, 17-30.

41. Cavaletto, M., Ghezzi, A., Burlando, B., Evangelisti, V., Ceratto, N., Viarengo, A. (2002) Effect of hydrogen peroxide on antioxidant enzymes and metallothionein level in the digestive gland of Mytilus galloprovincialis. Comp. Biochem. Physiol. C. Toxicol. Pharmacol., 131(4), 447-55.

26. Châtel, A., Faucet-Marquis, V., Perret, M., Gourlay-Francé, C., Uher, E., PfohlLeszkowicz, A., Vincent-Hubert, F. (2012) Genotoxicity assessment and detoxification induction in Dreissena polymorpha exposed to benzo[a]pyrene. Mutagenesis, 27(6), 703-711. 
50. Contardo-Jara, V., Pflugmacher, S., Nutzmann, G., Kloas, W., Wiegand, C. (2010) The beta receptor blocker metoprolol alters detoxification processes in the non-target organism Dreissena polymorpha. Environ. Pollut., 158, 2059-66.

48. Grebenjuk, V.A., Kuusksalu, A., Kelve, M., Schutze, J., Schroder, H.C., Muller, W.E. (2002) Induction of (2'-5')oligoadenylate synthetase in the marine sponges Suberites domuncula and Geodia cydonium by the bacterial endotoxin lipopolysaccharide. Eur. J. Biochem., 269, 1382-92.

17. Guerlet, E., Ledy, K., Meyer, A. and Giambérini, L. (2007). Towards a validation of a cellular biomarker suite in native and transplanted zebra mussels: A 2-year integrative field study of seasonal and pollution-induced variations. Aquatic Toxicology, 81(4), 377-388.

65. Hankinson, O. (1993) Research on the aryl hydrocarbon (dioxin) receptor is primed to take off. Arch. Biochem. Biophys., 300, 1-5.

53. Herreno-Saenz, D., Evans, F.E., Beland, F.A., Fu, P.P. (1995) Identification of two N2deoxyguanosinyl DNA adducts upon nitroreduction of the environmental mutagen 1nitropyrene. Chem Res Toxicol., 8(2):269-77.

29. Kirouac, K.N., Basu, A.K., Ling, H. (2013) Replication of a carcinogenic nitropyrene DNA lesion by human Y-family DNA polymerase. Nucleic Acids Res., 41(3):2060-71.

44. Krezel A., Hao Q, Maret, W. (2007) The zinc/thiolate redox biochemistry of metallothionein and the control of zinc ion Xuctuations in cell signaling Archives of Biochemistry and Biophysics 463, 188-200

71. Kurelec, B. (1995) Reversion of the multixenobiotic resistance mechanism in gills of marine mussel Mytilus galloprovincialis by a model inhibitor and environmental modulators of P170-glycoprotien. Aquat. Toxicol., 33, 93-103.

61. Lambert, I.B., Carroll, C., Laycock, N., Duval, L., Whiteway, J., Lawford, I., Turner, G., Booth, R., Douville, S., Nokhbeh, M.R. (1998) The mutational specificity of 1-nitroso-6nitropyrene in the lacI gene of Escherichia coli strains deficient in nucleotide excision repair. Mutagenesis, 13(1):9-18.

21. Le Goff, J., Gallois, J., Pelhuet, L., Devier, M.H., Budzinski, H., Pottier, D., André, V., Cachot, J. (2006) DNA adduct measurements in zebra mussels, Dreissena polymorpha, Pallas: Potential use for genotoxicant biomonitoring of fresh water ecosystems. Aquatic Toxicology, 79, 55-64.

42. Maret, W. (2000) The function of Zn metallothionein: A link between cellular Zn and redox state. J. Nutr., 130 (5), 1455s-1458s.

43. Maret W. (2003) Cellular Zinc and Redox States Converge in the Metallothionein/Thionein Pair. J. Nutr., 133 (5), 1460s-1462s.

12. Miet, K., Le Menach, K., Flaud, P.M., Budzinski, H., Villenave, E. (2009a) Heterogeneous reactions of ozone with pyrene1-hydroxypyrene and 1-nitropyrene adsorbed on particles, Atmospheric Environment, 43, 3699-3707. 
13. Miet K., Le Menach K., Flaud P.M., Budzinski H., Villenave E. (2009b) Heterogeneous reactivity of pyrene and 1-nitropyrene with NO2: Kinetics, product yields and mechanism, Atmospheric Environment, 43, 837-843.

39. Minier, C., Abarnou, A., Jaouen-Madoulet, A., Le Guellec, A.M., Tutundjian, R., Bocquené, G., Leboulenger, F. (2006) A pollution-monitoring pilot study involving contaminant and biomarker measurements in the Seine Estuary, France, using zebra mussels (Dreissena polymorpha). Environ. Toxicol. Chem., 25, 112-9.

34. Navarro, A., Faria, M., Barata, C., Pina, B. (2011) Transcriptional response of stress genes to

metal exposure in zebra mussel larvae and adults. Environ. Pollut., 159, 100-7.

37. Pain, S., Parant, M. (2003) Multixenobiotic defense mechanism (MDMX) in bivalves. $C$. R. Biol., 326, 659-72.

38. Pain, S., Parant, M. (2007) Identification of multixenobiotic defence mechanism (MXR) background activities in the freshwater bivalve Dreissena polymorpha as reference values for its use as biomarker in contaminated ecosystems. Chemosphere, 67, 1258-63.

49. Pfaffl, M.W. (2001) A new mathematical model for relative quantification in real-time RT-PCR. Nucleic Acids Res., 29, 45.

45. Pfohl-Leszkowicz, A., \& Castegnaro, M. (2005). Further arguments in favour of direct covalent binding of Ochratoxin A (OTA) after metabolic biotransformation. Food Additives \& Contaminants Suppl. 1, 75-87

46. Philipps, D.H., Castegnaro, $M$ et al (1999) Standardization and validation of DNA adduct postlabelling methods: report of interlaboratory trials and production of recommended protocols, Mutagenesis, 14, 301-315.

25. Pisoni, M., Cogotzi, L., Frigeri, A., Corsi, I., Bonacci, S., Iacocca, A., Lancini, L., Mastrototaro, F., Focardi, S., Svelto, M. (2004) DNA adducts, benzo(a)pyrene monooxygenase activity, and lysosomal membrane stability in Mytilus galloprovincialis from different areas in Taranto coastal waters (Italy). Environmental Research, 96, 163-175.

57. Prevodnik, A., Lilja, K., Bollner, T. (2007) Benzo[a]pyrene up-regulates the expression of the proliferating cell nuclear antigen (PCNA) and multixenobiotic resistance polyglycoprotein (P-gp) in Baltic Sea blue mussels (Mytilus edulis L.). Comp. Biochem. Physiol. C. Toxicol. Pharmacol., 145, 265-74.

9. Ringuet, J., Albinet, A., Leoz-Garziandia, E., Budzinski, H., Villenave, E. (2012a). Diurnal/nocturnal concentrations and sources of particulate-bound PAHs, OPAHs and NPAHs at traffic and suburban sites in the region of Paris (France), Science of the Total Environment, 437, 297-305.

10. Ringuet, J., Albinet, A., Leoz-Garziandia, E., Budzinski, H., Villenave, E. (2012b). 
Reactivity of polycyclic aromatic compounds (PAHs, NPAHs and OPAHs) adsorbed on natural aerosol particles exposed to atmospheric oxidants, Atmospheric Environment, 61, 1522.

11. Ringuet, J., Leoz-Garziandia, E., Budzinski, H., Villenave, E., Albinet, A. (2012c). Particle size distribution of nitrated and oxygenated polycyclic aromatic hydrocarbons (NPAHs and OPAHs) on traffic and suburban sites of a European megacity: Paris (France), Atmospheric Chemistry and Physics, 12(18), 8877-8887.

22. Rocher, B., Le Goff, J., Peluhet, L., Briand, M., Manduzio, H., Gallois, J., Devier, M.H., Geffard, O., Gricourt, L., Augagneur, S., Budzinski, H., Pottier, D., Andre, V., Lebailly, P., Cachot, J. (2006). Genotoxicant accumulation and cellular defence activation in bivalves chronically exposed to waterborne contaminants from the Seine River. Aquat. Toxicol., 79, $65-77$.

56. Seo, Y.R., Jung, H.J. (2004) The potential roles of p53 tumor suppressor in nucleotide excision repair (NER) and base excision repair (BER). Exp. Mol. Med., 36, 505-9.

24. Skarphéinsdóttir, H, Ericson, G, Dalla Zuanna, L, Gilek, M (2003): Tissue differences, dose-response relationship and persistence of DNA adducts in blue mussels (Mytilus edulis L.) exposed to benzo[a]pyrene. Aquatic Toxicology, 62, 165-177.

68. Sole, M., Porte, C., Biosca, X., Mitchelmore, C.L., Chipman, J.K., Livingstone, D.R. (1996). Effects of the 'Aegean Sea' oil spill on biotransformation enzymes, oxidative stress and DNA-adducts in digestive gland of the mussel (Mytilus edulis L.). Comp. Biochem. Physiol., 113, 257-265.

4. Umbuzeiro, G.A., Franco, A., Martins, M.H., Kummrow, F., Carvalho, L., Schmeiser, H.H., Leykauf, J., Stiborova, M., Claxton, L.D. (2008). Mutagenicity and DNA adduct formation of $\mathrm{PAH}$, nitro-PAH, and oxy-PAH fractions of atmospheric particulate matter from São Paulo, Brazil. Mutat Res., 652(1), 72-80.

40. Viarengo, A., Burlando, B., Ceratto, N., Panfoli, I. (2000). Antioxidant role of metallothioneins: a comparative overview. Cell Mol. Biol., 46(2), 407-17.

67. Werner, E.E. (1998) Ecological experiments and a research program in community ecology. In Experimental ecology: issues and perspectives. Resetarits, W.J.J. and Bernardo, J., editors. Oxford University Press, Oxford, UK. pp. 3-26

64. Whitlock, J.P., Jr. (1999). Induction of cytochrome P4501A1. Annu. Rev. Pharmacol. Toxicol., 39, 103-25. 
Table 1.Primer sequences (5'-3') used in RT-qPCR

\begin{tabular}{|l|l|l|l|l|}
\hline Gene & Short name & Forward primer & Reverse primer \\
\hline Ribosomal protein S3 & S3 & CAGTGTGAGTCCCTGAGATACAAG & AACTTCATGGACTTGGCTCTCTG & Accession number \\
\hline P-glycoprotein & P-gp1 & CACCTGGACGTTACCAAAGAAGATATA & TCACCAACCAGCGTCTCATATTT \\
\hline Aryl-hydrocarbon receptor & AH-R & ATCACAGCGATGAGCCTCAG & AGACAGCATTGCGAGGTCAC \\
\hline Superoxide dismutase & SOD & GACAGCATGGCTTCCATGTG & AGGAGCCCCGTGAGTTTTG \\
\hline Catalase & CAT & ATCAGCCTGCGACCAGAGAC & GTGTGGCTTCCATAGCCGTT \\
\hline Glutathione S-transferase & GST & ATGATCTATGGCAACTATGAGACAGG & GAAGTACAAACAGATTGTAGTCCGC & EF194203 \\
\hline Heat-shock Protein 70 & HSP70 & GCGTATGGACTTGATAAGAACCTCA & GAACCCTCGTCGATGGTCA \\
\hline
\end{tabular}

Table 2. DNA adduct formation and induction of detoxification mechanisms in Dreissena polymorpha exposed to nitro-PAHs

Gills

Digestive glands

Low dose High dose Low dose High dose

$\begin{array}{lllll}\text { Adducts } & + & + & + & + \\ \text { AHR } & - & - & - & + \\ \text { SOD } & - & - & - & - \\ \text { CAT } & - & - & - & - \\ \text { GST } & - & - & - & - \\ \text { PgP } & - & + & - & + \\ \text { HSP70 } & - & - & - & + \\ \text { MT } & - & - & + & +\end{array}$


Fig.1. Example of DNA adduct patterns in gills and digestive glands from mussels exposed to 1- nitropyrene

A gills; $\mathrm{B}$ digestive gland; $\mathrm{C}$ scheme of adduct numbering in gills $\mathrm{D}$ scheme of adduct numbering in digestive glands

Fig. 2. Formation of DNA adduct in gills (A) and digestive glands (B) of D. polymorpha exposed to $50 \mu \mathrm{M}$ or $500 \mu \mathrm{M}$ of 1-nitropyrene for $48 \mathrm{~h}$ or 5 days

Fig.3Relative mRNA abundance values of AHR (A), CAT (B),SOD (C), GST (D), MT (E), HSP70 (F) and PgP (G) in gills of D. polymorpha exposed to $50 \mu \mathrm{M}$ or $500 \mu \mathrm{M}$ of 1 nitropyrene for $48 \mathrm{~h}$ or 5 days, analysed by qRT-PCR. Results are normalised with the reference gene S3. (*): data significantly different compared to control group $(\mathrm{p}<0.05)$.

Fig. 4. Relative mRNA abundance values of AHR (A), CAT (B), SOD (C), GST (D), MT (E), $\mathrm{HSP} 70(\mathrm{~F})$ and $\operatorname{PgP}(\mathrm{G})$ in digestive glands of $D$. polymorpha exposed to $50 \mu \mathrm{M}$ or $500 \mu \mathrm{M}$ of 1 -nitropyrene for $48 \mathrm{~h}$ or 5 days, analysed by qRT-PCR. Results are normalised with the reference gene S3. $(*)$ : data significantly different compared to control group $(p<0.05)$.

Figure 1

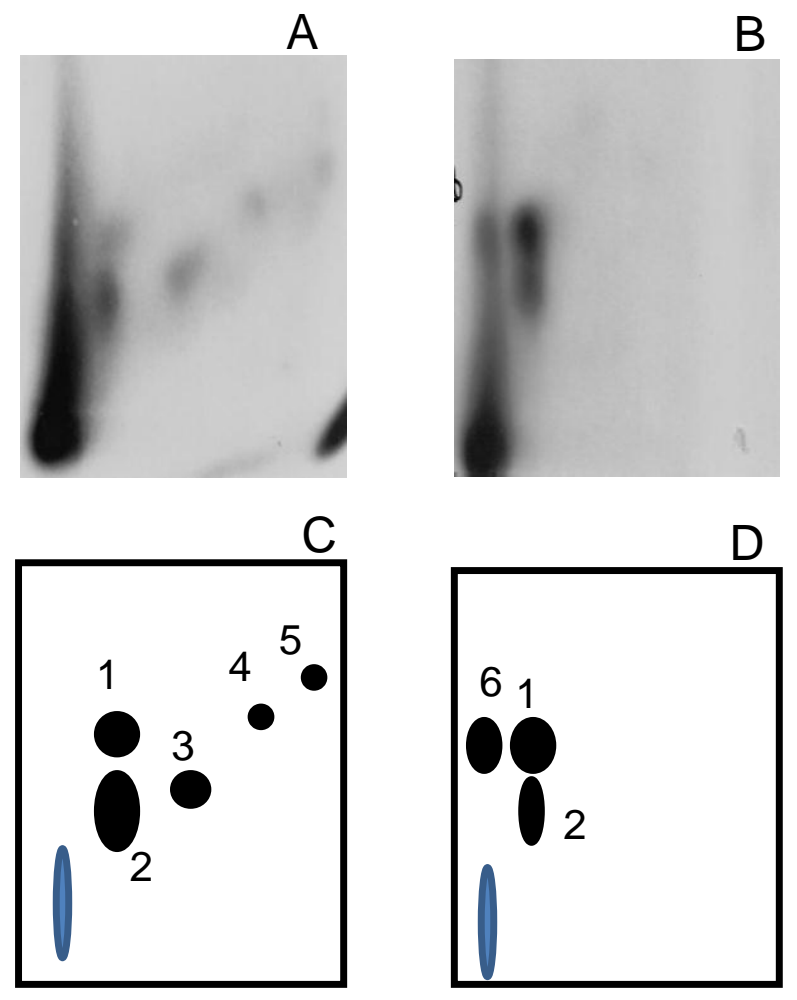


Figure 2

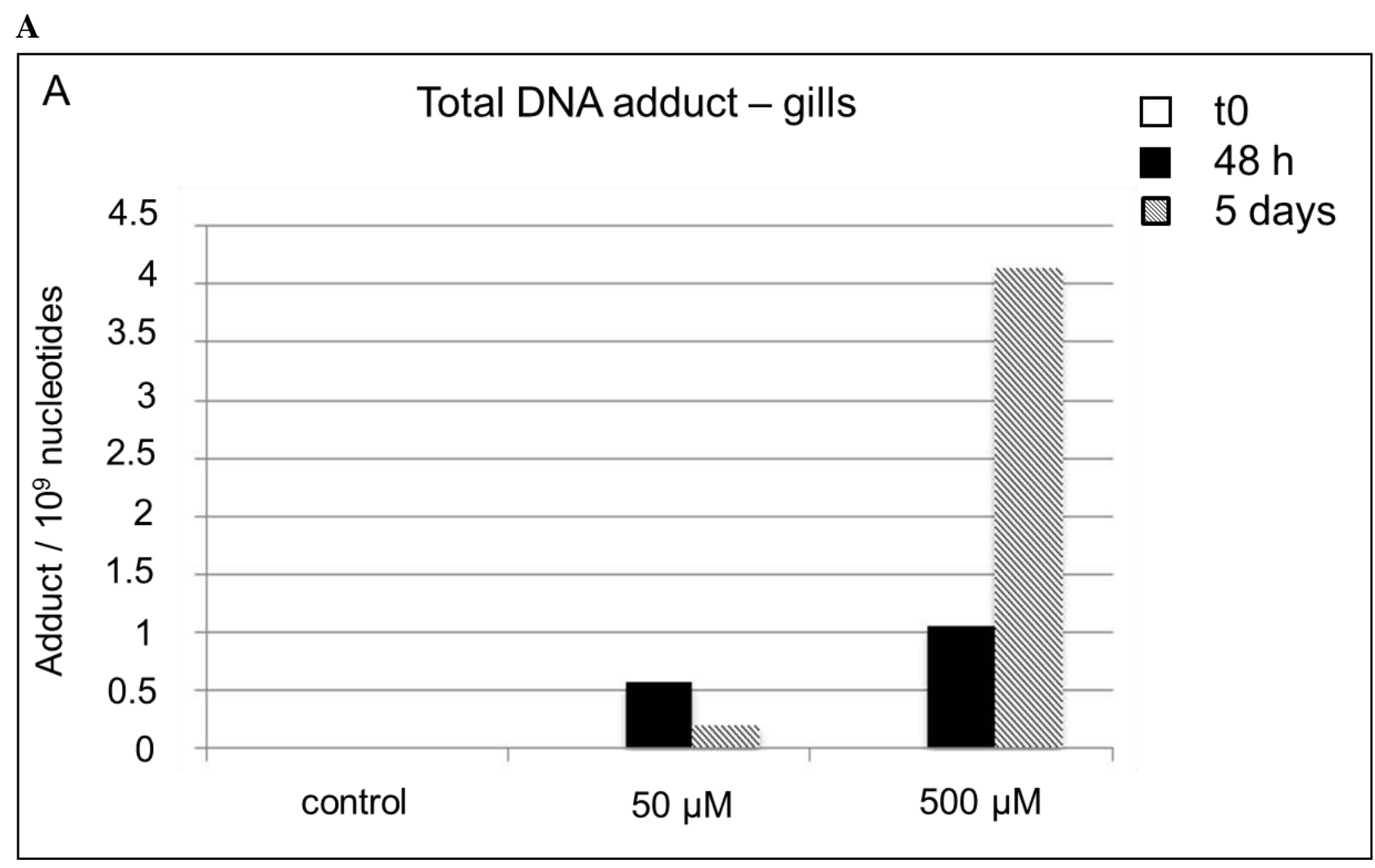

B.

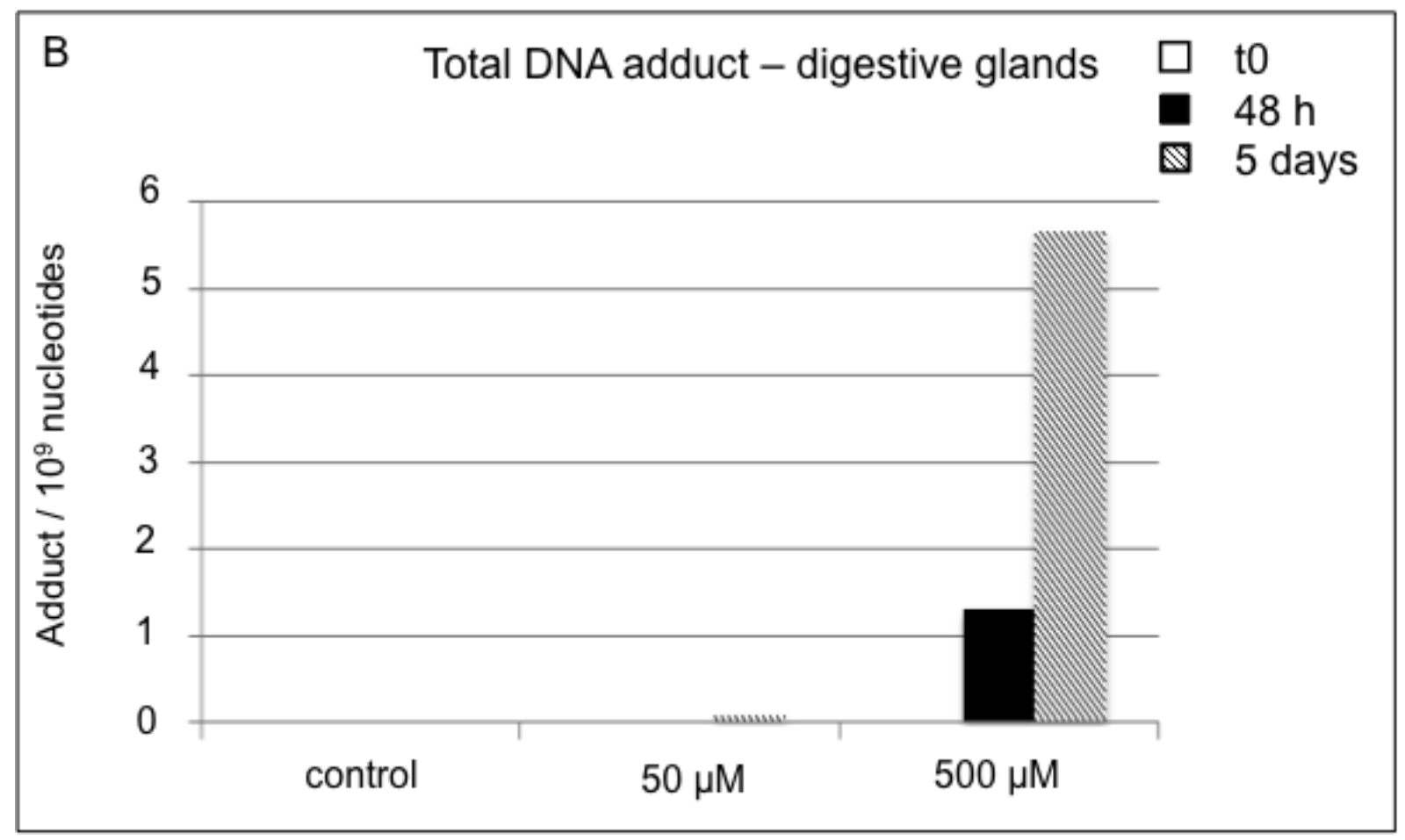


Figure 3

A.

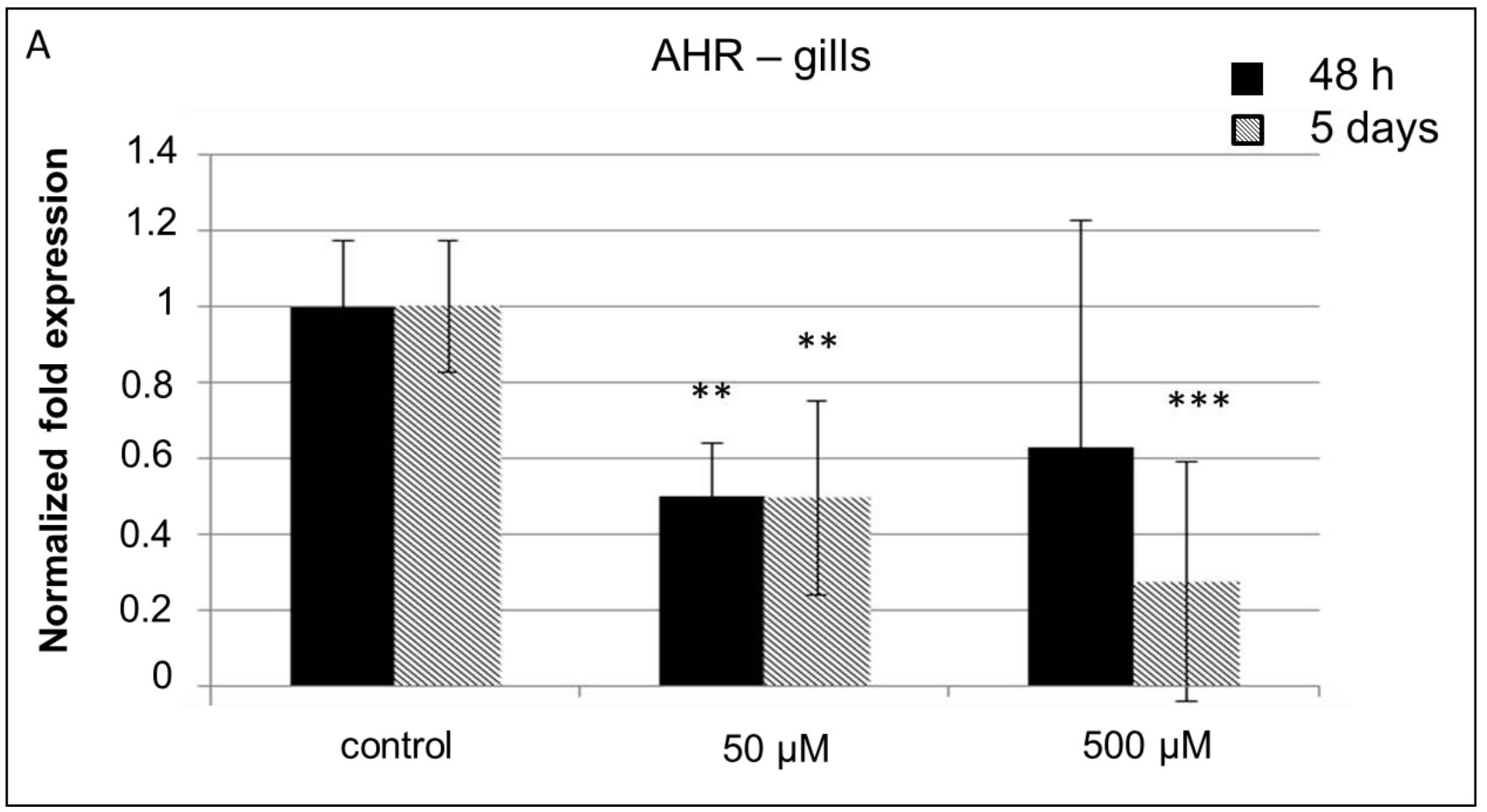

B.

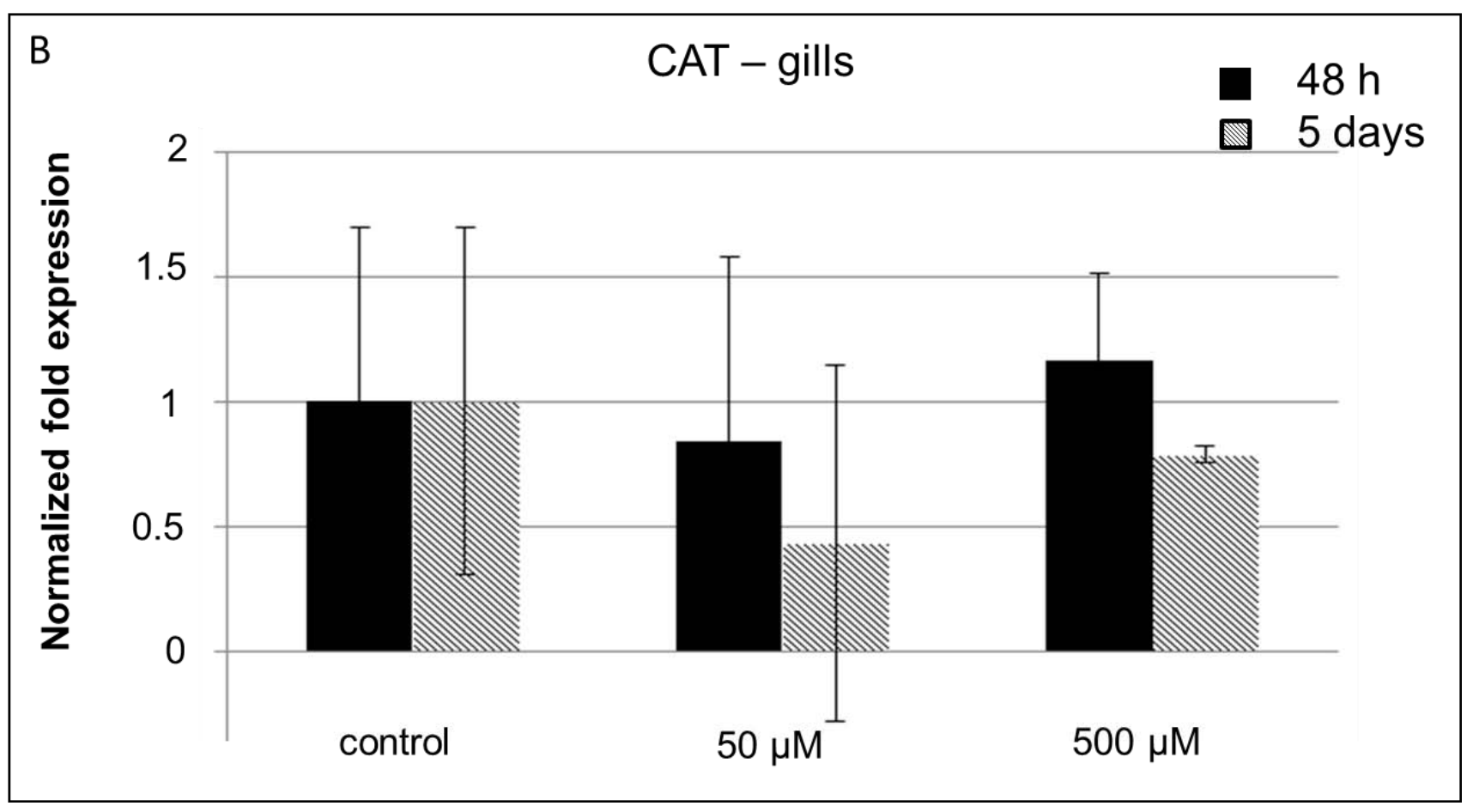


C.

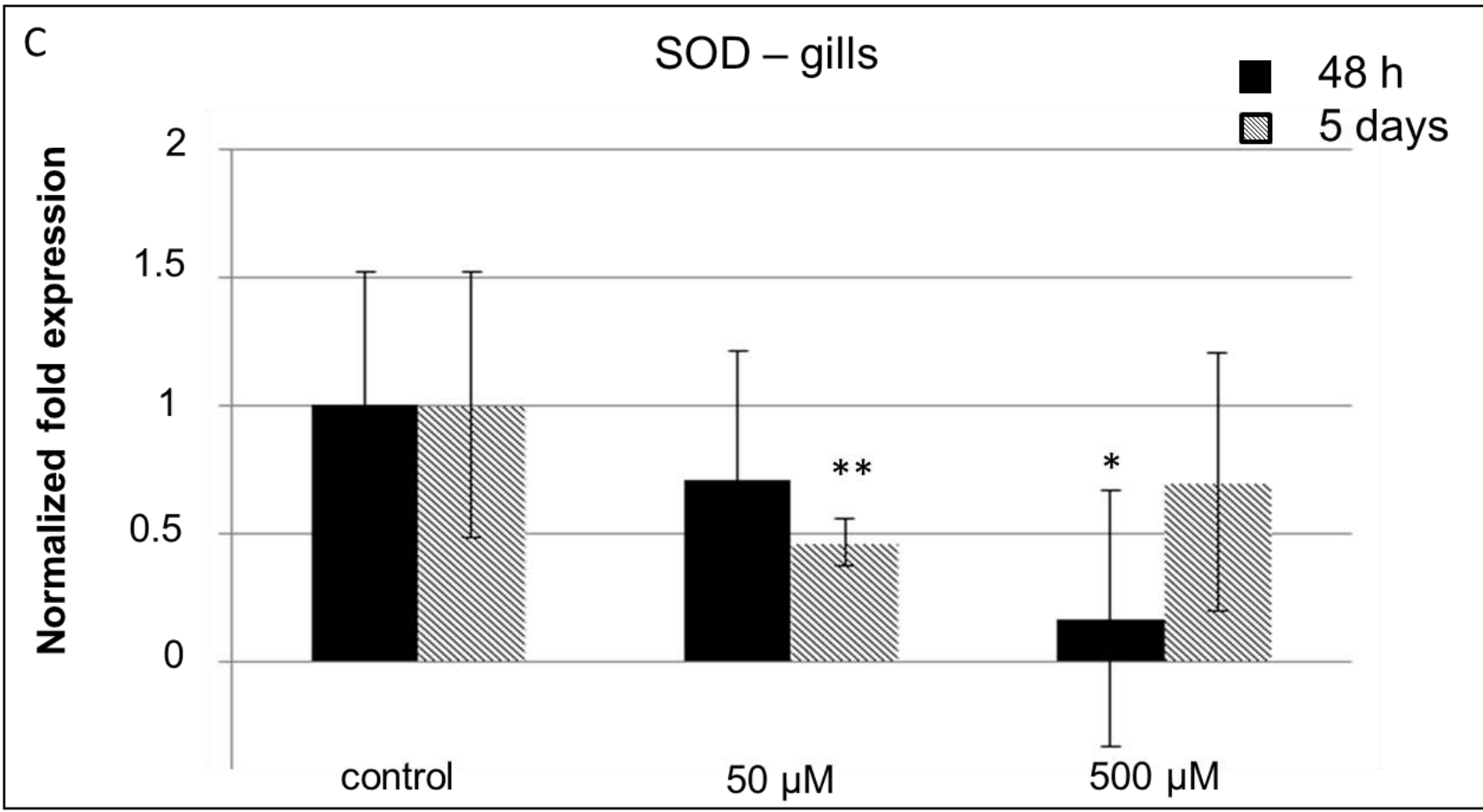

D.

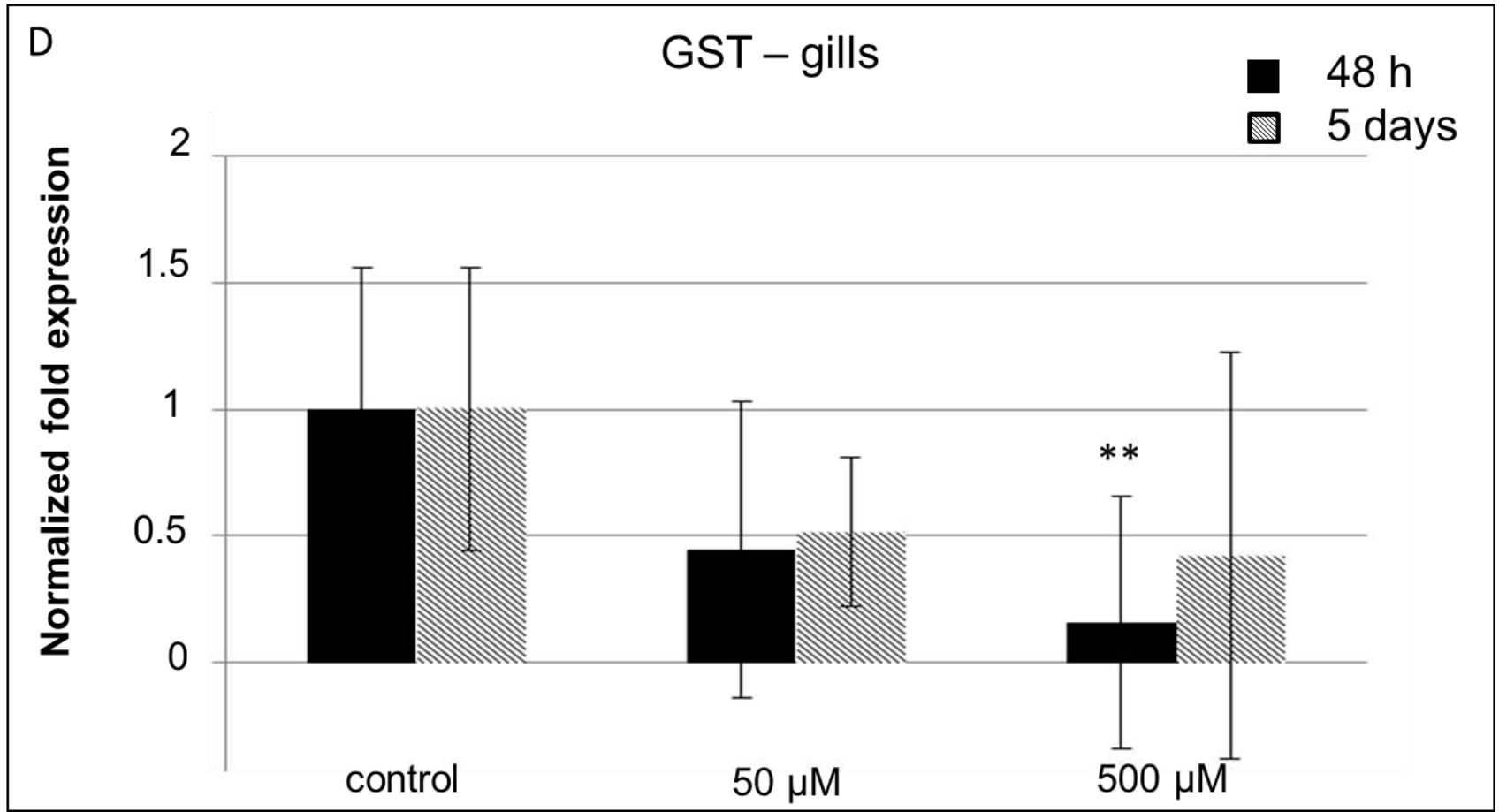


E.

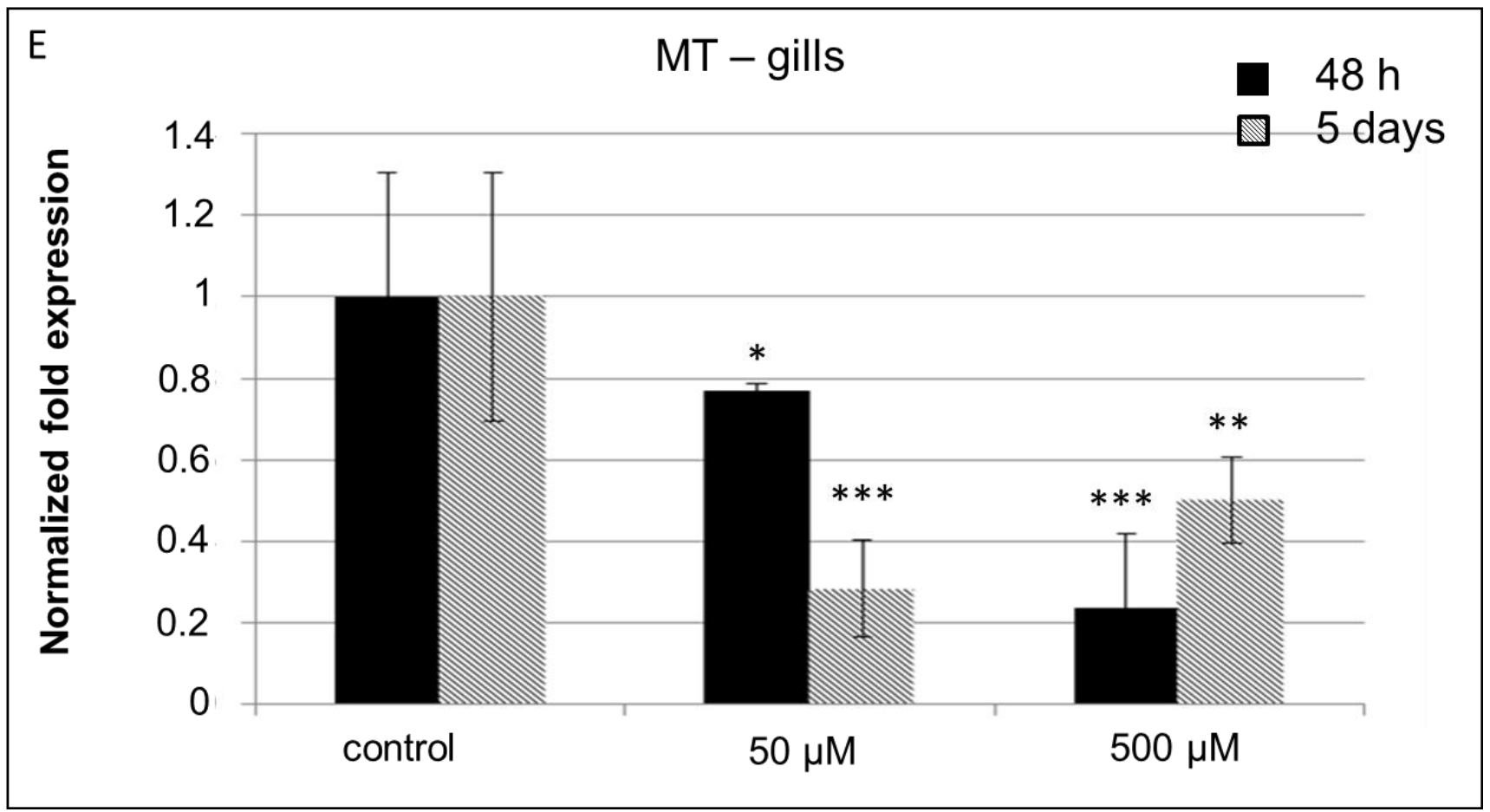

F.

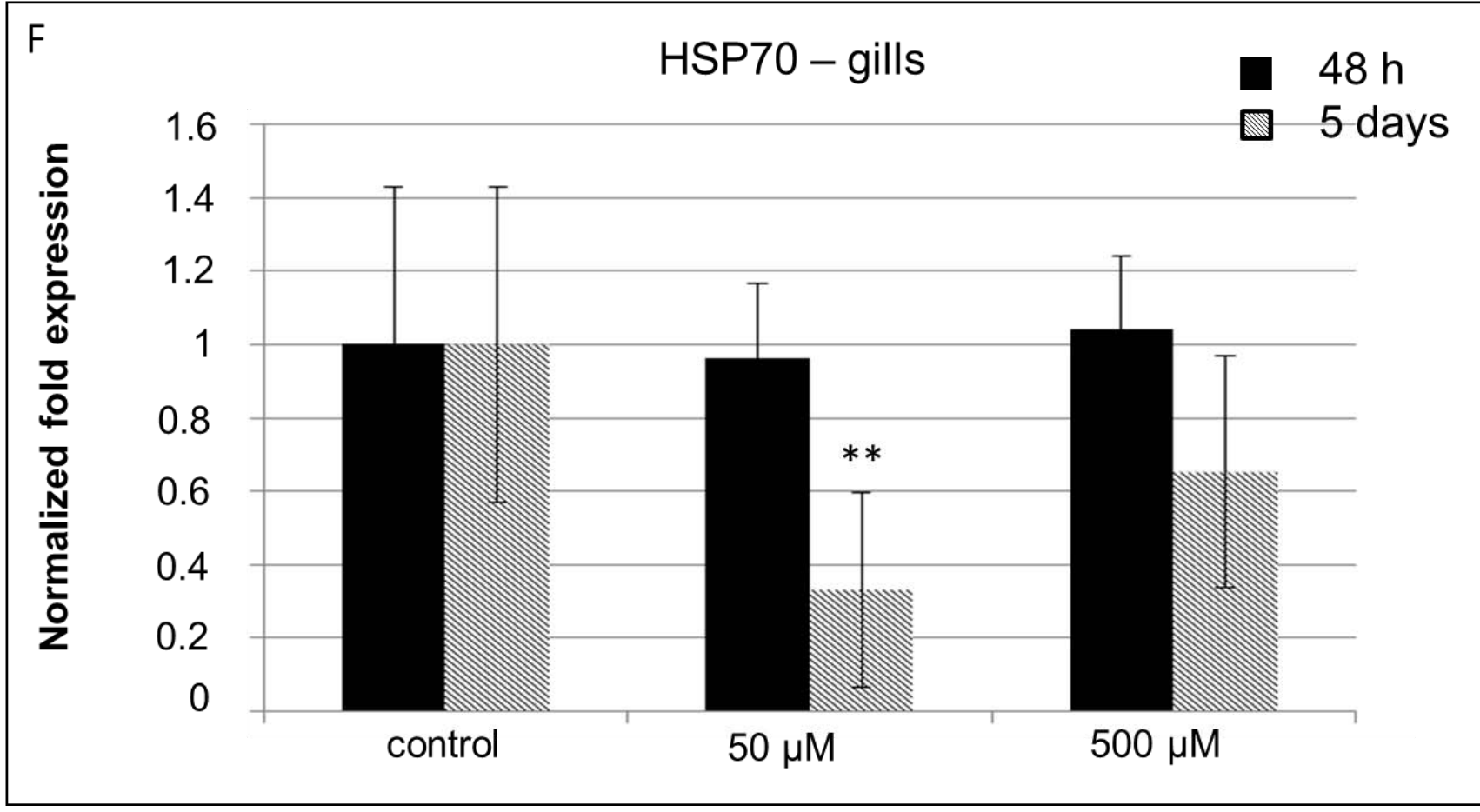


G.

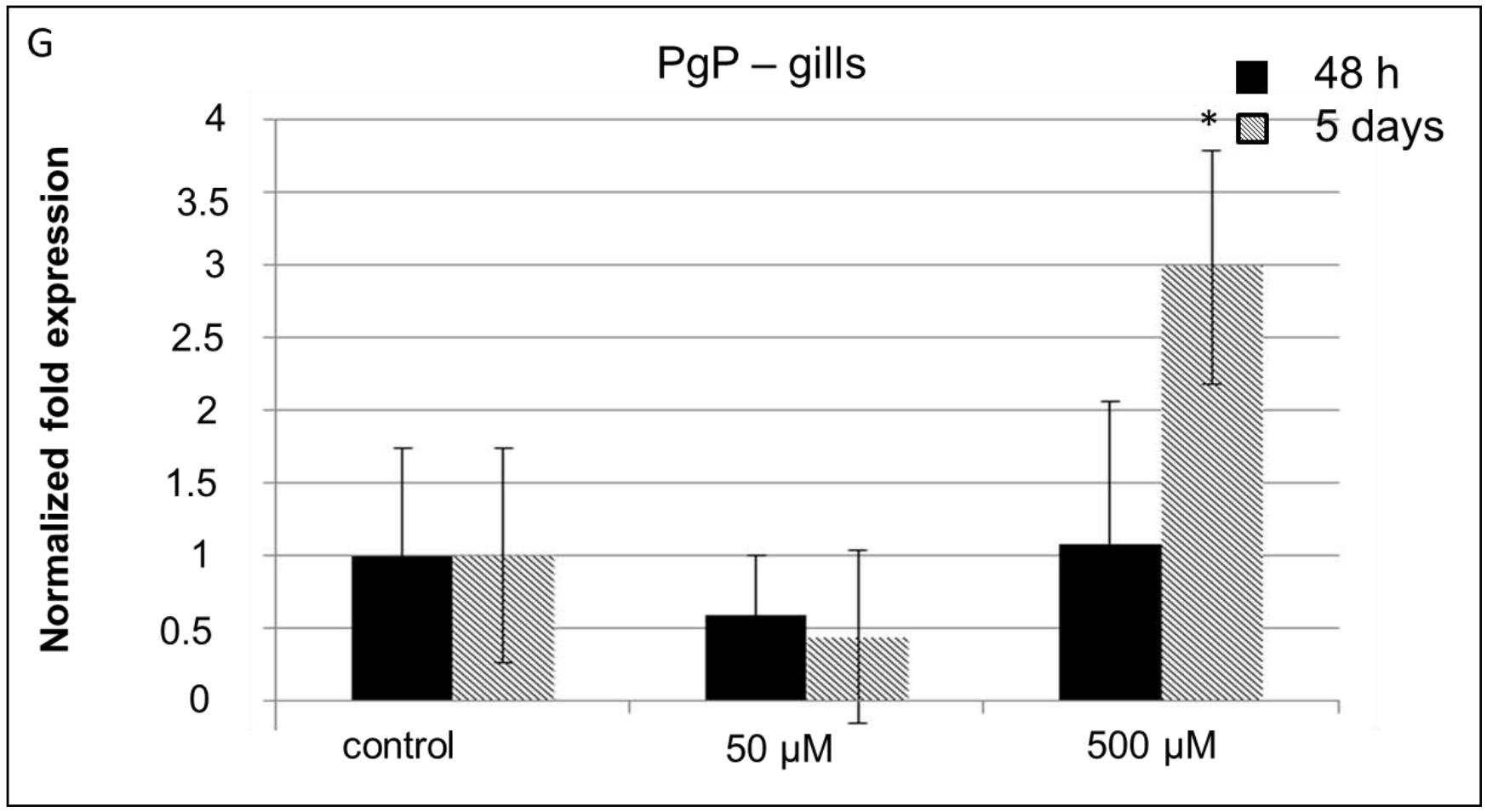

Figure 4

A.

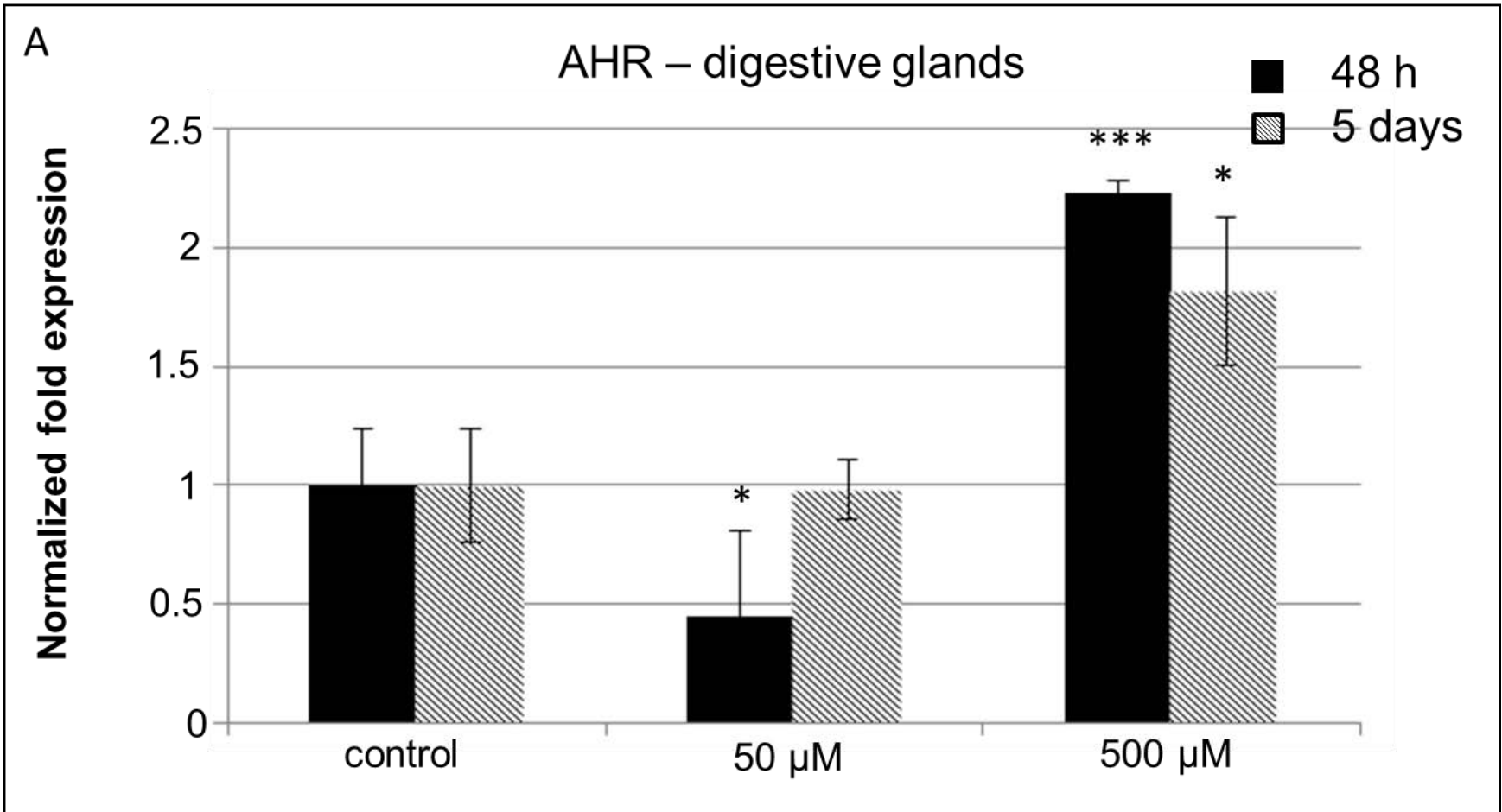


B.

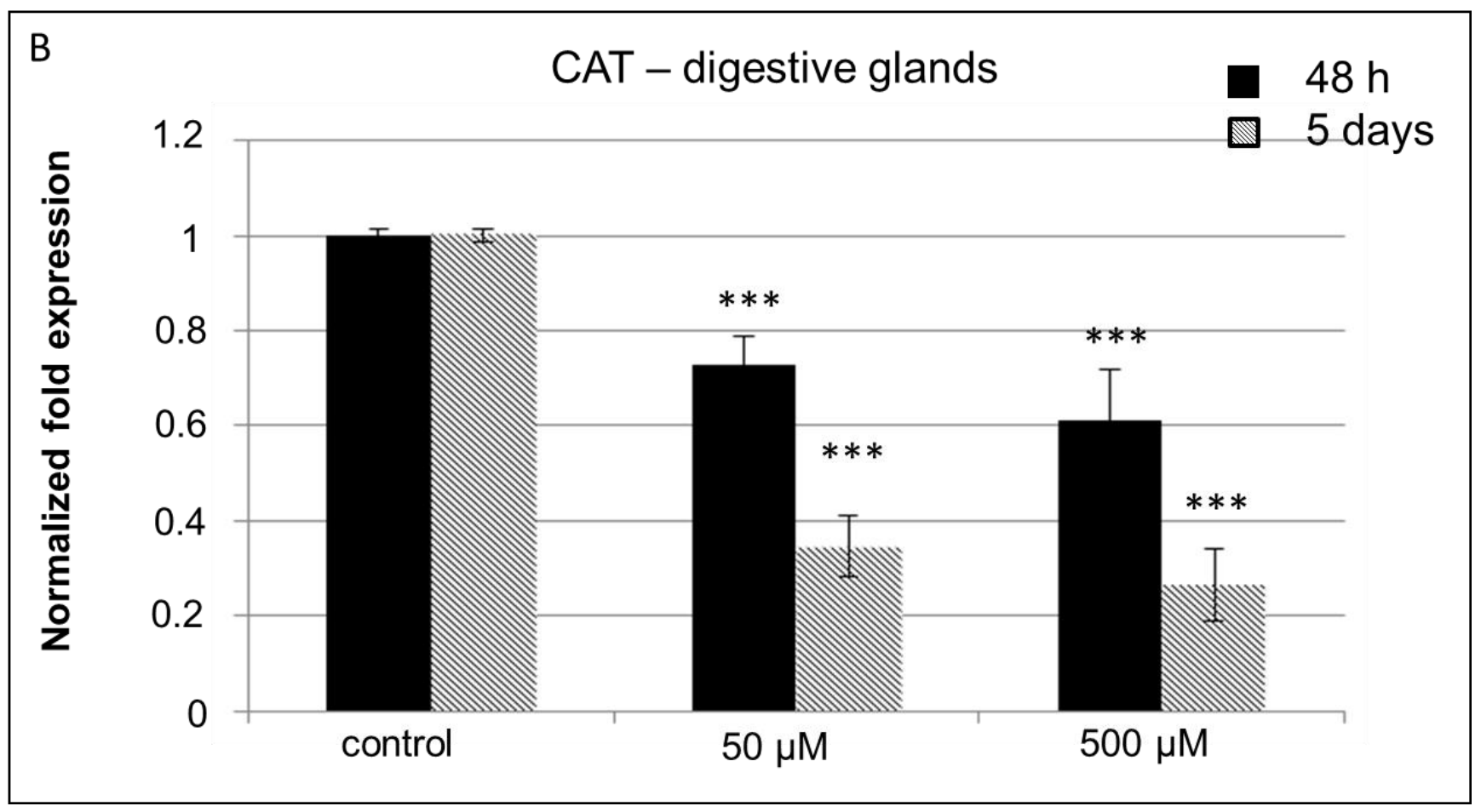

C.

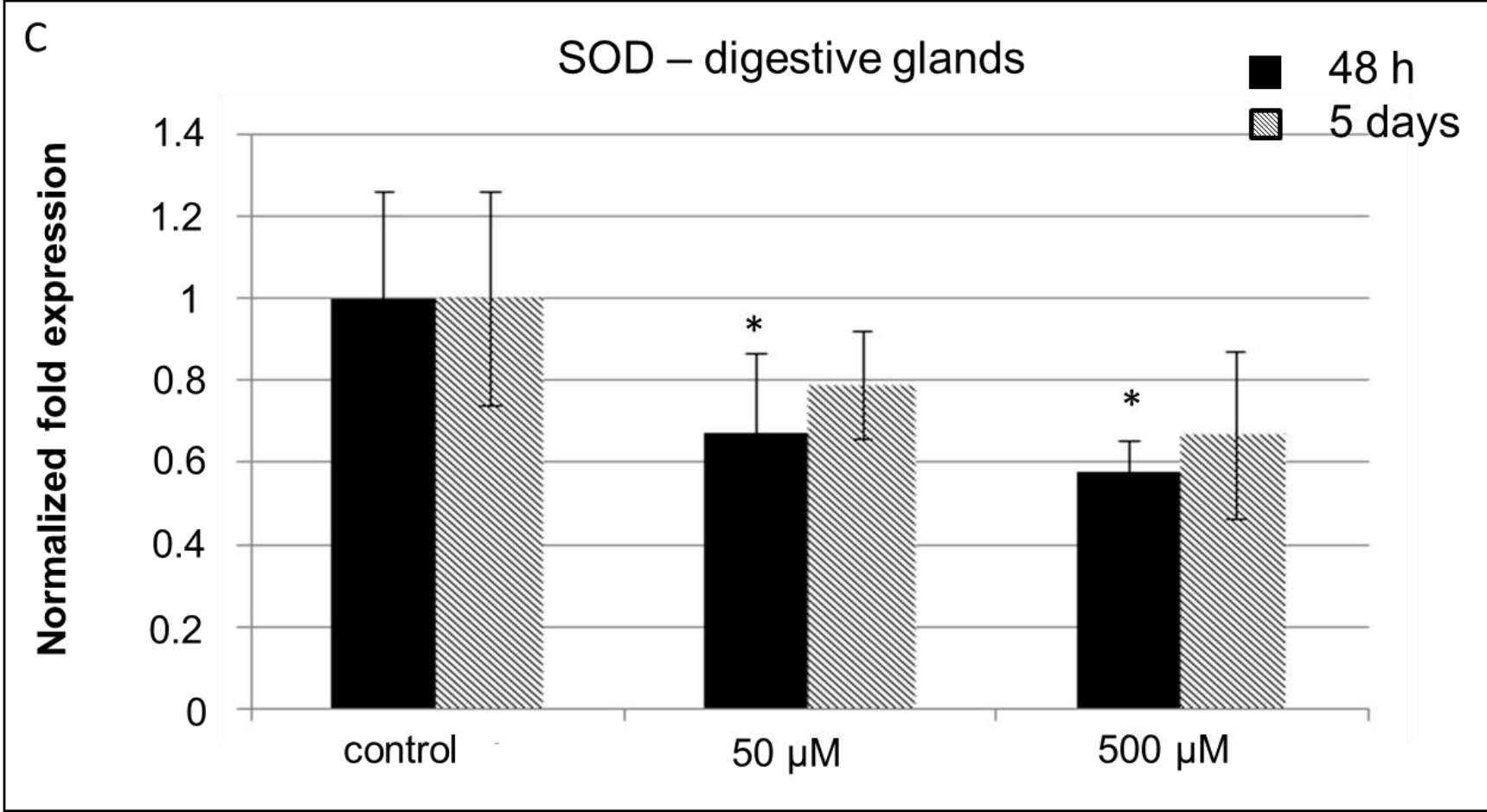


D.

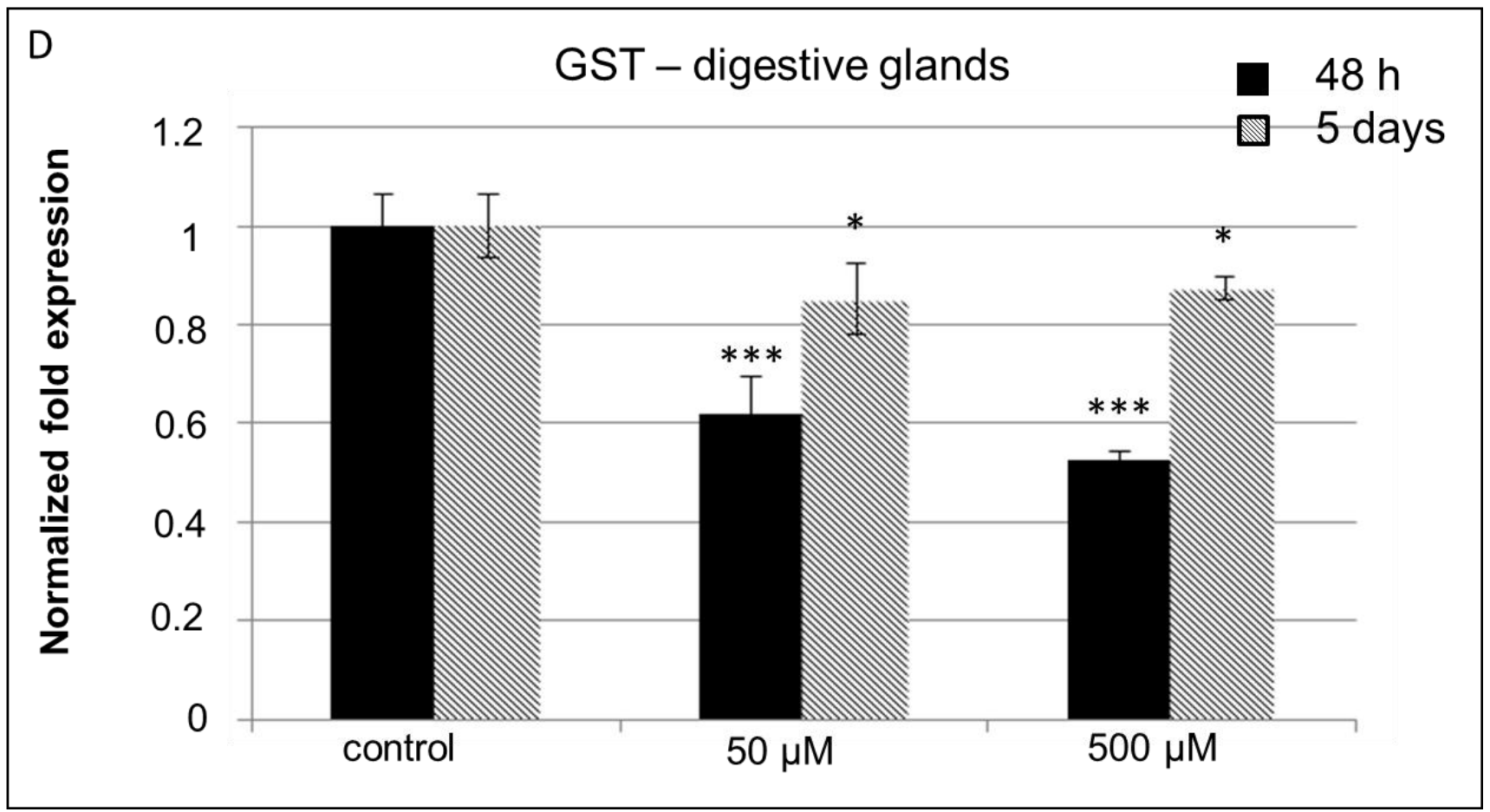

E.

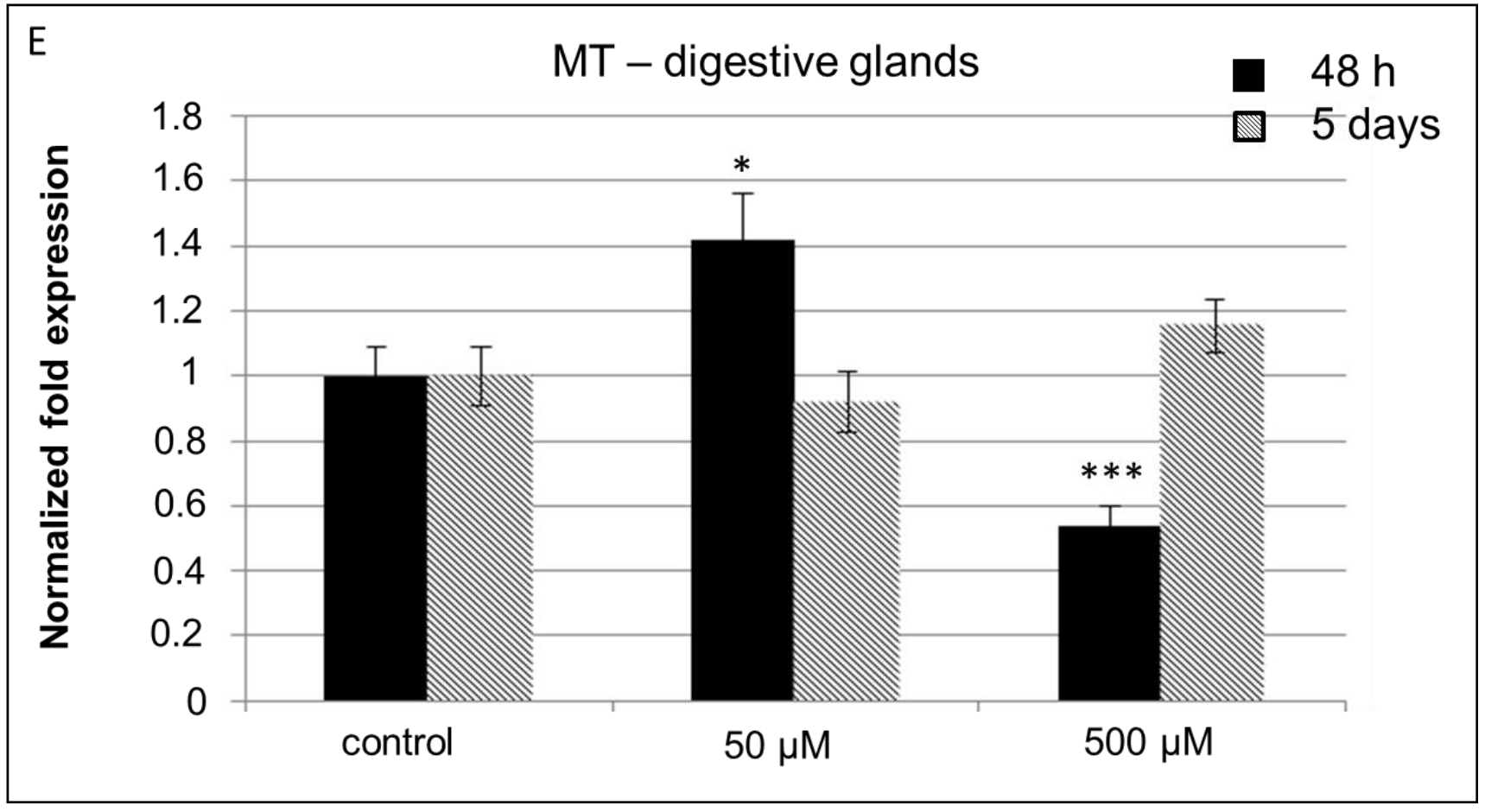


F.

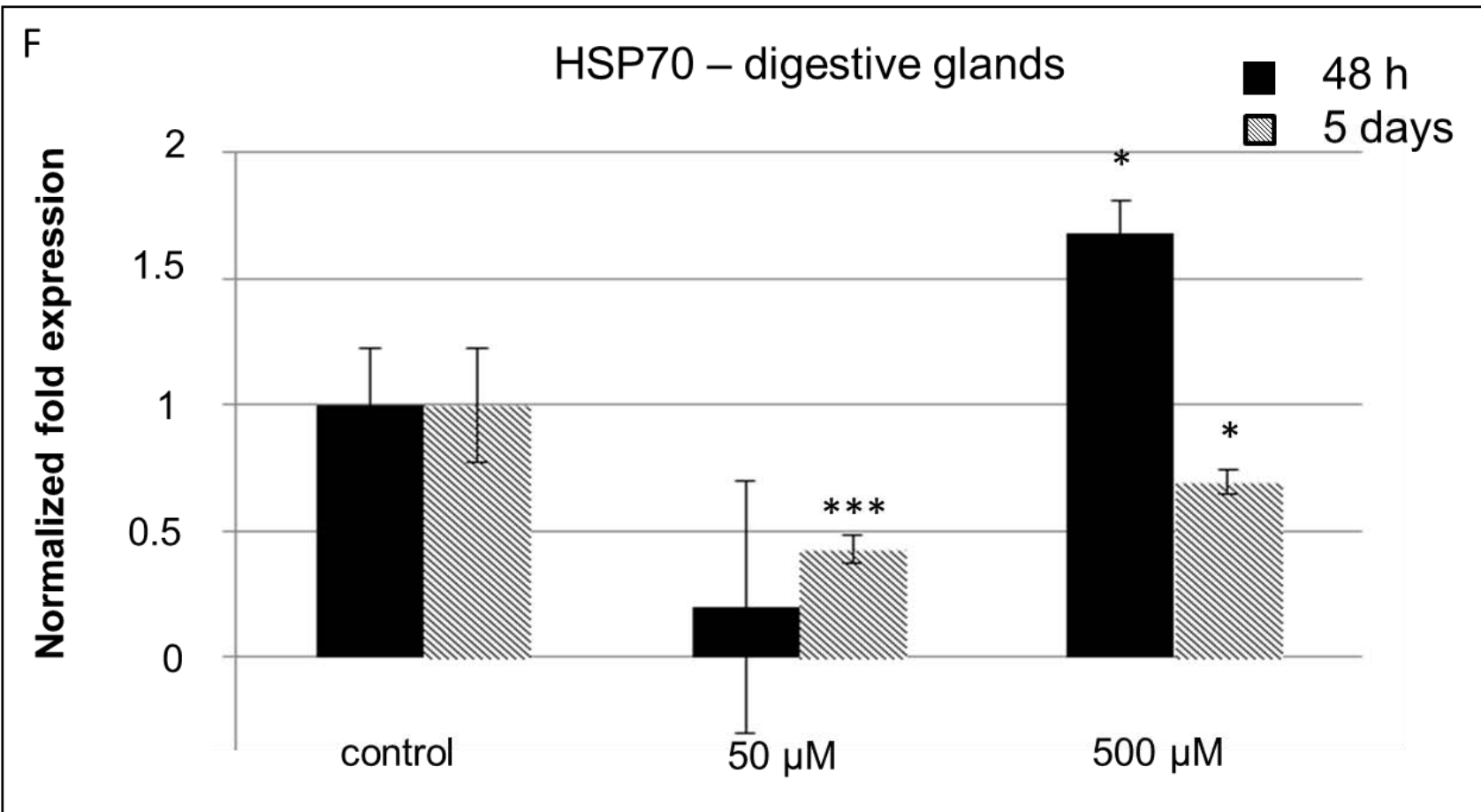

G.

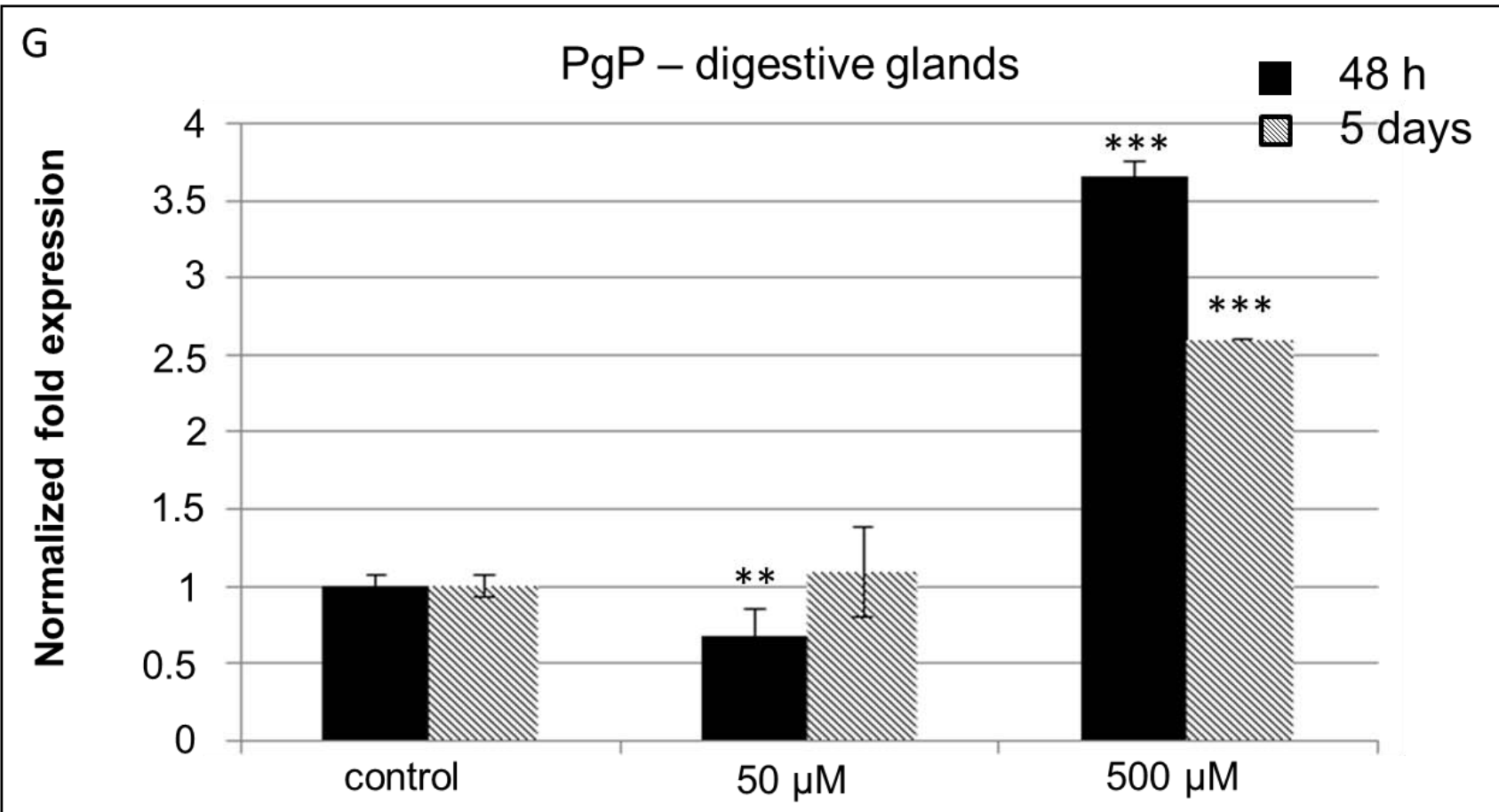

